\title{
LONG-TERM STUDY OF ATMOSPHERIC MERCURY DEPOSITION AT MONITORING STATIONS IN LITHUANIA
}

\author{
J. Šakalys, K. Kvietkus, I. Garbarienè, and A. Urba \\ State Research Institute Center for Physical Sciences and Technology, Sauletekio 3, 10257 Vilnius, Lithuania \\ Email: kestutis.kvietkus@ftmc.lt
}

Received 12 July 2018; revised 4 October 2018; accepted 15 October 2018

\begin{abstract}
The results of the long-term study of atmospheric mercury concentrations in the rain water carried out at the Aukštaitija and Žemaitija integrated monitoring stations are presented in this work. The bulk precipitation samples at both stations were collected every week during the 2007-2017 period. The mercury measurement method is based on the absorption of radiation by mercury vapour at the $253.7 \mathrm{~nm}$ line. The monthly samples of precipitation after preparation were analysed using a mercury analyzer 'Gardis' developed at our institution. The average annual concentrations, deposition amounts and trends of mercury in the precipitation over the period of 2007-2017 were analysed. The tendency of average monthly mercury concentrations in the precipitation at the Žemaitija station was continuously increasing before 2011, however, after 2012 it has a decreasing tendency which was contrary to that at the Aukštaitija station. At the same time, the tendencies of average monthly amounts of mercury deposited with precipitation showed decreasing amounts, especially at the Žemaitija station. Explanation of the above-mentioned phenomenon is complicated and the main reason is very changeable air mass trajectories and irregularity of precipitation.
\end{abstract}

Keywords: mercury, atmosphere, precipitation, concentration, deposition

PACS: $92.60 . \mathrm{Sz}, 92.60 . \mathrm{Fm}, 92.60$.Jq, $92.70 . \mathrm{Cr}$

\section{Introduction}

Human activities and natural processes emit gaseous mercury into the atmosphere, therefore, the atmospheric deposition to the ground surface and aquatic ecosystems is the major source of mercury [1]. Deposition rates of mercury increased globally with the increasing industrial activity during the last century [2]. However, this trend has decreased in the recent years [3-5]. Long-term monitoring of total gaseous mercury (TGM) at two European background sites has confirmed a decreasing tendency in atmospheric mercury since 1990 [4-6]. At the Canadian Arctic site any significant changes of annual average mercury concentrations have not been detected since 1995 [ []. Strict regulations were applied to the major anthropogenic mercury emission sources in Europe and North America [8-11], however, mercury emissions increased in develop- ing countries $110,12,13$. Long-term monitoring of mercury concentrations at the Mace Head atmospheric research station on the west coast of Ireland did not show any trend in the concentration levels during the measurement period. A slight increase in the concentration levels was determined when only air masses clearly of the marine origin were used and investigated [9-11, 14, 15,. However, the global decrease of TGM concentrations between 1990 and 1996 was detected [16] and it was assumed that it was probably caused by a substantial decrease of anthropogenic emissions. This information consists of a large-scale geographical distribution and can evaluate the worldwide trend of atmospheric mercury.

The atmospheric emission, transport and deposition of mercury to the Earth's surface are complex: many large direct sources of mercury have been eliminated or greatly reduced; thus, the dominant pathway for the new mercury input is via atmospheric 
emission, transformation, transport and deposition [17]. Deposited mercury can migrate in ecosystems by water pathways and even low concentrations can damage ecosystems as well as they are dangerous for human health [18, 19]. Therefore, it is important to know the amount and trends of deposited toxic compounds on the Earth's surface.

The aim of the study is to provide long-term regional variations and trends of mercury concentrations in the atmospheric depositions and to evaluate possible quantitative changes in Lithuania during the period of 2007-2017.

\section{Materials and methods}

\subsection{Location of sampling sites and sampling methodology}

Precipitation samples were collected at the Aukštaitija and Žemaitija integrated monitoring stations (IMS) in Lithuania. The Aukštaitija IMS is located in the east of Lithuania $\left(55^{\circ} 26^{\prime} 26^{\prime \prime} \mathrm{N}\right.$, $26^{\circ} 04^{\prime} 05^{\prime \prime} \mathrm{E}$ ) in a forested, hilly area about $300 \mathrm{~km}$ from the Baltic Sea. The nearest residential areas are Tauragnai, Utena ( 12 and $26 \mathrm{~km}$ west of the station) and Ignalina (17 km southeast of the station). The climate is characterized as moderately cold with high precipitation. The long-term annual mean temperature is $5.8^{\circ} \mathrm{C}$ and the amount of precipitation is $648 \mathrm{~mm}$.

The Žemaitija IMS is located in the west of Lithuania $\left(56^{\circ} 00^{\prime} 42^{\prime \prime} \mathrm{N}, 21^{\circ} 52^{\prime} 33^{\prime \prime} \mathrm{E}\right)$. The Žemaitija IMS is situated in the strict reserve zone of Žemaitija National Park at the $50 \mathrm{~km}$ distance from the Baltic Sea. The annual average air temperature is $5.9^{\circ} \mathrm{C}$ and the annual average amount of precipitation reaches up to $788 \mathrm{~mm}$. The distance between both stations is about $300 \mathrm{~km}$.

The bulk precipitation samples at both stations were collected every week during the 2007-2017 periods. Three bulk collectors were used at each station. The measurement data from three parallel collectors were averaged to avoid the influence of the accidental contamination on the final results [20].

\subsection{Analysis of liquid samples using a mercury analyzer 'Gardis'}

The mercury measurement method is based on the absorption of radiation by mercury vapour at the $253.7 \mathrm{~nm}$ line. The mercury is first reduced to the elemental state using the procedure outlined in the EPA Method 245.1 [21]. Air is bubbled through the liquid sample, carrying the mercury vapour to the absorption cell. The $253.7 \mathrm{~nm}$ mercury line emitted by the lamp is absorbed by the mercury vapour in the cell. The result is transmitted to the digital screen on which the concentration of mercury can be directly read.

The monthly samples of precipitation after preparation [21] were analysed using the AAS Mercury analyzer 'Gardis' [22-24]. Standard reference materials were used for checking the calibration procedure. The measurement methodologies were tested every year by EMEP international intercalibration exercises. The results from the intercalibration exercises have shown that analytical methods used for the analysis of environmental samples give reliable and representative results [25, 26]. Detailed information on the procedure of measurements and intercalibration exercises is presented in our previous papers [27-29].

The experimental setup used for the detection of mercury vapour released from liquids is shown in Fig. 1. For the routine semi-automatic analysis of liquid samples, the following operations have to be performed: pour the sample into a bubbler, recap the bubbler, and press the analyzer 'Start' button. The needed amount of the liquid sample was evaluated from the expected $\mathrm{Hg}$ concentration in the sample, taking into account that the sample has to contain the total amount of $\mathrm{Hg}$ in the range from 0 to 2000 picograms. For example, when the expected $\mathrm{Hg}$ concentration was in the range from 10 to $20000 \mathrm{ng} \mathrm{L}^{-1} \mathrm{Hg}$, we used $0.1 \mathrm{~mL}$ of the sample to obtain response from 1 to 2000 pg. [30].

When working with acidic solutions, the soda or other similar pre-trap was used in between the bubbler and the analyzer. The soda trap was useful in two ways: firstly, acidic vapour emitted from the bubbler was neutralized and thus the surface of the internal gold traps was protected; secondly, in the case of accidental flooding with liquid, soda shrank immediately and protected the analyzer gas train from flooding with the liquid.

In the course of use, soda became wet, shrank and even blocked the air flow completely. Therefore, 


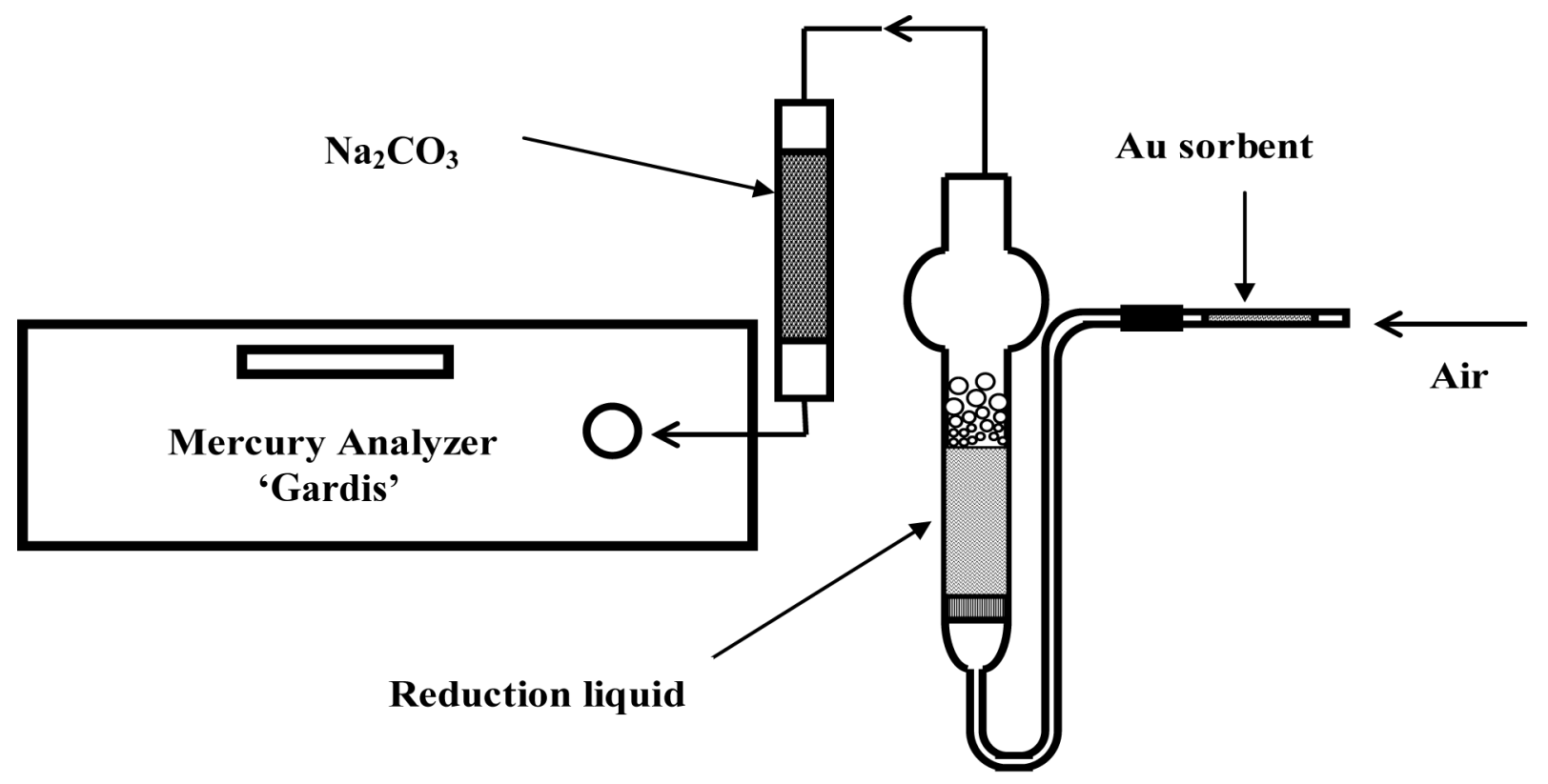

Fig. 1. Principal scheme of the mercury concentration measurement in the precipitation samples.

it was dried and replaced from time to time. To remove traces of mercury from the newly prepared soda filter, we placed it in a furnace up to $300^{\circ} \mathrm{C}$ for a few hours.

It was possible to extend the lifetime of the soda trap by using the silica gel filter prior to soda but additional testing was required to make sure that such a filter does not contribute to the mercury blank and/or absorb mercury vapour released from liquid. The activated carbon filter (or gold sorbent) was installed at a bubbler inlet to avoid the mercury vapour intake from the ambient air.

We found it convenient to use a bubbler much larger than the volume of a single portion of the analyzed liquid and to pour a strongly reducing solution into the bubbler once prior to series of measurements. Then a single analysis was performed by simply uncapping the bubbler, adding the sample, re-capping the bubbler and pressing the analyzer 'START' button.

The time which was necessary for the complete reaction and release of all elemental mercury vapours from the liquid depended on the bubbler volume and construction, the analysed liquid properties and conditions of the reaction. The optimal time was found empirically, by performing a repeated analysis of the same sample.

When analysing liquids, we did calibration against liquid standards, diluted to yield similar doses of mercury as expected from the samples, and from time to time also checked the analyzer calibration and functioning of all the system by the standard addition method. We usually used the single (instead of double) trap analyzer configuration for the liquid analysis, as less time-consuming [30]. The above-mentioned device and the mercury measuring method were improved several times later [31, 32].

\subsection{Data analysis}

Taking into consideration the large scattering of the measured data and assuming that the variation of the trend and the amplitude are described by the dependence of the second order and using the method of the least squares (MLS), we can expect that the yearly variation of the data will vary as a sinusoid with the phase shift $\varphi$ and the variation period $T$ [33]. Thus, the amplitude of the concentration can be described as $A_{C}=A t^{2}+B t+C$ and the trend can be described as $T_{C}=k_{7} t^{2}+k_{8} t+k_{9}$. Then the mercury concentration will be described by the equation

$$
c(t)=\left(A t^{2}+B t+C\right) \sin (\omega t+\varphi)+k_{7} t^{2}+k_{8} t+k_{9} .
$$

After the transformation of $\sin (\omega t+\varphi)$ and multiplication operations it is possible to describe it in the following form: 


$$
\begin{aligned}
& k_{1} t^{2} \sin \omega t+k_{2} t^{2} \cos \omega t+k_{3} t \sin \omega t+k_{4} t \cos \omega t \\
& +k_{5} \sin \omega t+k_{6} \cos \omega t .
\end{aligned}
$$

Here $k_{1}=A \cos \varphi, k_{2}=A \sin \varphi, k_{3}=B \cos \varphi$, $k_{4}=B \sin \varphi, k_{5}=C \cos \varphi, k_{6}=C \sin \varphi$ and $\frac{2 \pi}{T}=\omega$.

Regarding the above descriptions Eq. (1) can be presented in the following form:

$$
\begin{aligned}
& c(t)=k_{1} t^{2} \sin \omega t+k_{2} t^{2} \cos \omega t+k_{3} t \sin \omega t+k_{4} t \cos \omega t \\
& +k_{5} \sin \omega t+k_{6} \cos \omega t+k_{5} \sin \omega t+k_{6} \cos \omega t+k_{8} t+k_{9} \cdot(2)
\end{aligned}
$$

The least squares sum of all experimental data is defined as follows:

$$
S=\sum_{i=1}^{n}\left(c_{i}-c\left(t_{i}\right)\right)^{2} .
$$

Here $c_{i}$ are the experimental values of mercury concentration in the air and $c\left(t_{i}\right)$ are the calculated values.

$$
1,2,3 \ldots 9 \text {. }
$$

The sum $S$ is minimal when $\frac{\partial S}{\partial k_{j}}=0$, here $j=$
$3 \ldots 9$.

After solving the system of Eqs. (2) and (3) obtained from the above condition (4), we will find the coefficients $k_{j}$. These coefficients inserted in Eq. (2) will give us the dependence of the mercury concentration in the precipitation with the period $T$. In our case the yearly variation period is $T=365.25$ days. The pollutant concentration in the air varies not as strongly as a sinusoidal form, thus the harmonics with the periods $T / 2, T / 3, T / 4, T / 5$ and $T / 6$ are calculated. Later, from the experimental data the calculated data are subtracted and the same procedure is repeated already with the periods $T / 2, T / 3, T / 4, T / 5$ and $T / 6$, etc. and the new harmonics are determined. In this case the obtained average pollutant concentration variation in the air corresponds to the average monthly concentration course. The amplitudes of separate harmonics can vary from negative values to positive values or vice versa. This allows correcting the average yearly concentration course at the beginning and at the end of the experiment. An additional advantage of this method is a possibility to calculate the course of the concentration when measured experimental data are not complete (when we have periods without experimental data).

\section{Results and discussion}

\subsection{Mercury concentration, deposited amount and tendencies}

The tendencies of average monthly mercury concentrations (Fig. 2) show that at the Žemaitija IMS the concentrations were increasing till 2011 and decreasing after 2012. Our observations reveal that the $\mathrm{Hg}$ concentration increased by $10 \%$ each year in the period of 2007-2012, while a decrease of $9 \%$ in each year was observed in the period of 2012-2017. On the contrary, at the Aukštaitija IMS the mercury concentrations were decreasing till 2011 (average annual decrease is about 6\%) and were increasing after 2012 (average annual increase is about 9\%). However, the changes of the concentration amplitude are insignificant at both stations.

Explanation of the above-mentioned concentration variation is complicated and it could be related to changeable air mass trajectories and the large irregularity of precipitation at both stations.

The average monthly mercury amounts (or mass) deposited with precipitation per month on the square metre of Earth's surface (in other words 'surface load') show the decreasing tendency at both stations (Fig. 3). The reason for the abovementioned decreasing surface load can be related with the decreasing amount of precipitation at both stations.

The data presented in Fig. 4 and Table 1 show that a larger amount of precipitation was observed at the Žemaitija IMS and the variation interval is also large, respectively (it can be seen from me$\operatorname{dian}\left(h_{\mathrm{m}}\right)$ and $\sigma$ values).

However, the median and $\sigma$ values of the mercury concentration in precipitation are larger/ higher at the Aukštaitija IMS. It is determined by larger scavenging of mercury with precipitation from the atmosphere. Deposited monthly mercury amounts with precipitation are larger at the Žemaitija IMS, though the mercury concentration in precipitation is lower. However, the main reason for the above-mentioned event is the higher amount of deposited precipitation.

It was established that the precipitation amount to the Earth's surface in 2007-2017 varied from 8 to $173 \mathrm{~mm}$ at the Aukštaitija IMS and from 5 to 

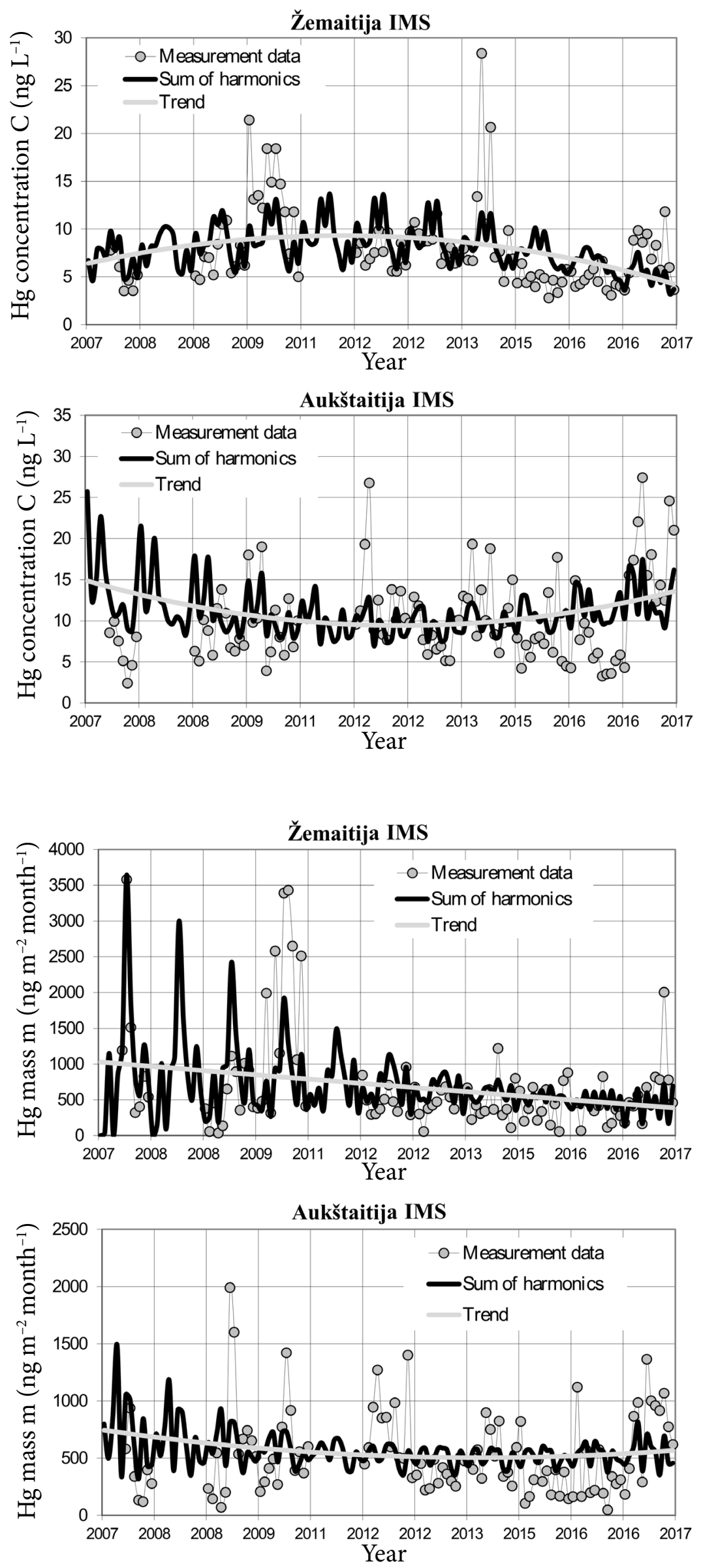

Fig. 2. Average monthly mercury concentrations in precipitation deposited at the Žemaitija and Aukštaitija integrated monitoring stations.
Fig. 3. Deposited monthly mercury amounts or mass on the square metre of the Earth's surface at the Žemaitija and Aukštaitija integrated monitoring stations. 

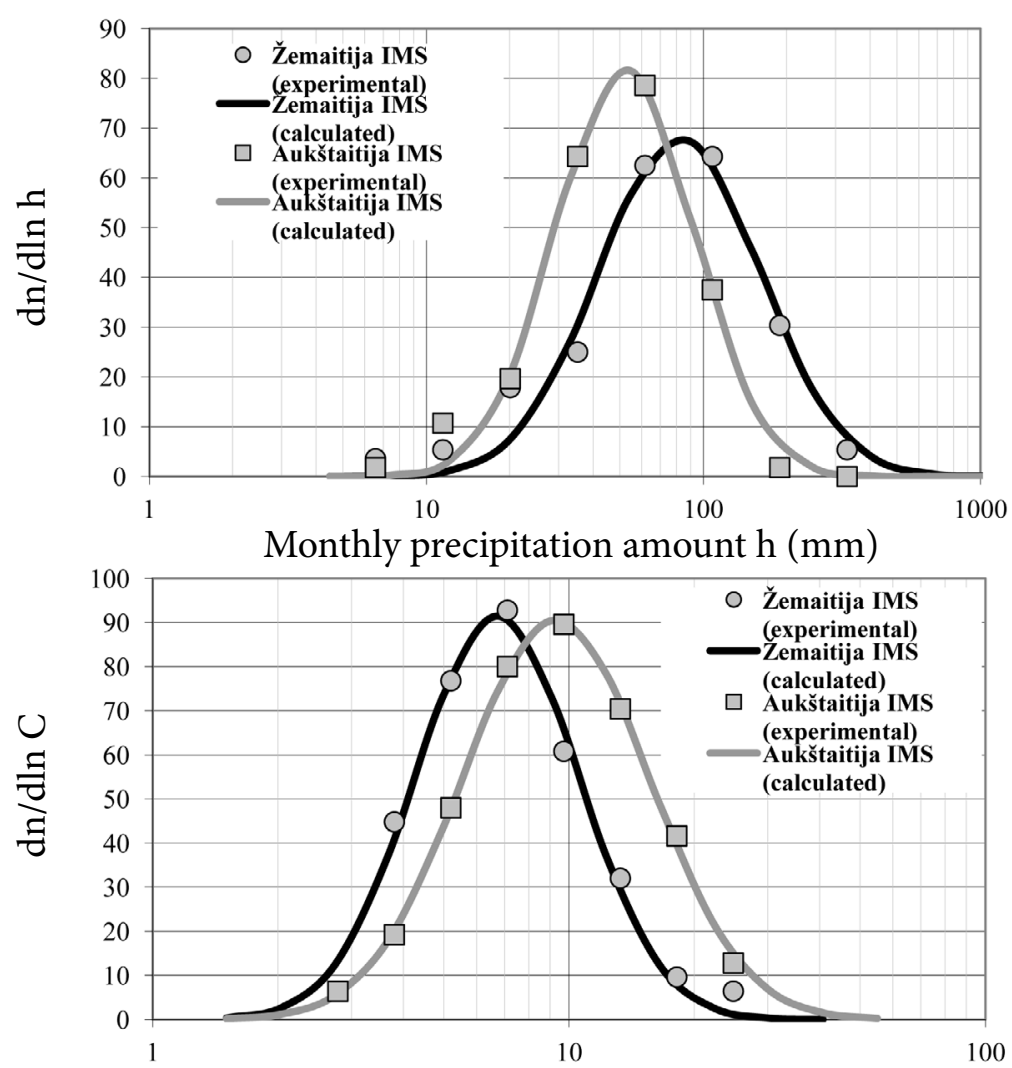

$\mathrm{Hg}$ concentration $\mathrm{C}\left(\mathrm{ng} \mathrm{L}^{-1}\right)$

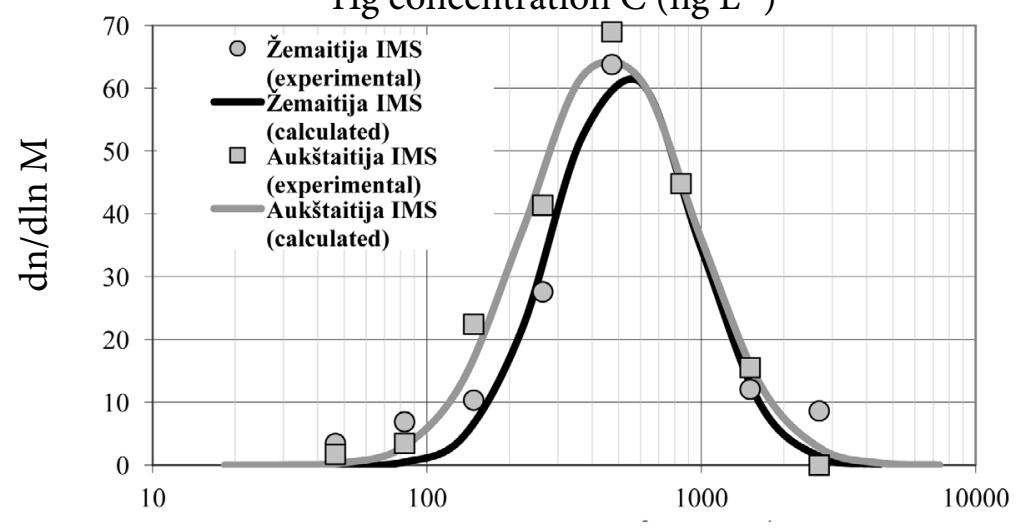

Hg mass $\mathrm{m}$ (ng m ${ }^{-2}$ month $\left.^{-1}\right)$
Fig. 4. Distribution of monthly precipitation amounts (dlnh), the mercury concentration in precipitation $(\mathrm{d} \ln \mathrm{C})$ and the deposited mercury mass (dlnm) at the Žemaitija and Aukštaitija integrated monitoring stations.
$426 \mathrm{~mm}$ at the Žemaitija IMS. The mercury concentration in the precipitation varied from 1.39 to $29 \mathrm{ng} \mathrm{L}^{-1}$ at the Aukštaitija IMS and from 2.78 to $28.4 \mathrm{ng} \mathrm{L}^{-1}$ at the Žemaitija IMS. The Earth's surface load by mercury varied from 47.8 to $1990 \mathrm{ng} \mathrm{m}^{-2}$ month $^{-1}$ at the Aukštaitija IMS and from 34.8 to $3580 \mathrm{ng} \mathrm{m}^{-2}$ month $^{-1}$ at the Žemaitija IMS.

The average monthly concentrations of mercury in precipitation deposited at the Žemaitija and Aukštaitija integrated monitoring stations are presented in Fig. 5. As seen from the figure,

Table 1 . The median values $\left(h_{\mathrm{m}}\right)$ of deposited monthly precipitation amounts, the mercury concentration in precipitation $\left(C_{\mathrm{m}}\right)$, mercury amounts $\left(\mathrm{m}_{\mathrm{m}}\right)$ deposited with precipitation and the standard deviation $(\sigma)$ values.

\begin{tabular}{cccc}
\hline \multirow{2}{*}{ Žemaitija IMS } & $h_{\mathrm{m}}=81.9 \mathrm{~mm}$ & $C_{\mathrm{m}}=6.72 \mathrm{ng} \mathrm{L}^{-1}$ & $\mathrm{~m}_{\mathrm{m}}=525 \mathrm{ng} \mathrm{m}^{-2} \mathrm{month}^{-1}$ \\
\cline { 2 - 4 } & $\sigma=1.95$ & $\sigma=1.57$ & $\sigma=1.80$ \\
\hline \multirow{2}{*}{ Aukštaitija IMS } & $h_{\mathrm{m}}=51.9 \mathrm{~mm}$ & $C_{\mathrm{m}}=9.31 \mathrm{ng} \mathrm{L}^{-1}$ & $\mathrm{~m}_{\mathrm{m}}=467 \mathrm{ng} \mathrm{m}^{-2} \mathrm{month}^{-1}$ \\
\cline { 2 - 4 } & $\sigma=1.77$ & $\sigma=1.68$ & $\sigma=2.01$ \\
\hline
\end{tabular}


the average yearly precipitation amount at the Žemaitija station is generally larger, however, the average mercury concentration in the precipitation is lower, but the deposited yearly average mercury amount is larger at the Žemaitija station. Explanation of the above-mentioned phenomenon could be only the main factor, such as the crucial influence of the total amount of precipitation [20].

\section{Conclusions}

It was established that the precipitation amount to the Earth's surface in 2007-2017 varied from 8 to $173 \mathrm{~mm}$ at the Aukštaitija IMS and from 5 to $426 \mathrm{~mm}$ at the Žemaitija IMS. The mercury concentration in the precipitation varied from 1.39 to $29 \mathrm{ng} \mathrm{L}^{-1}$ at the Aukštaitija IMS and from 2.78 to $28.4 \mathrm{ng} \mathrm{L}^{-1}$ at the Žemaitija IMS. The Earth's
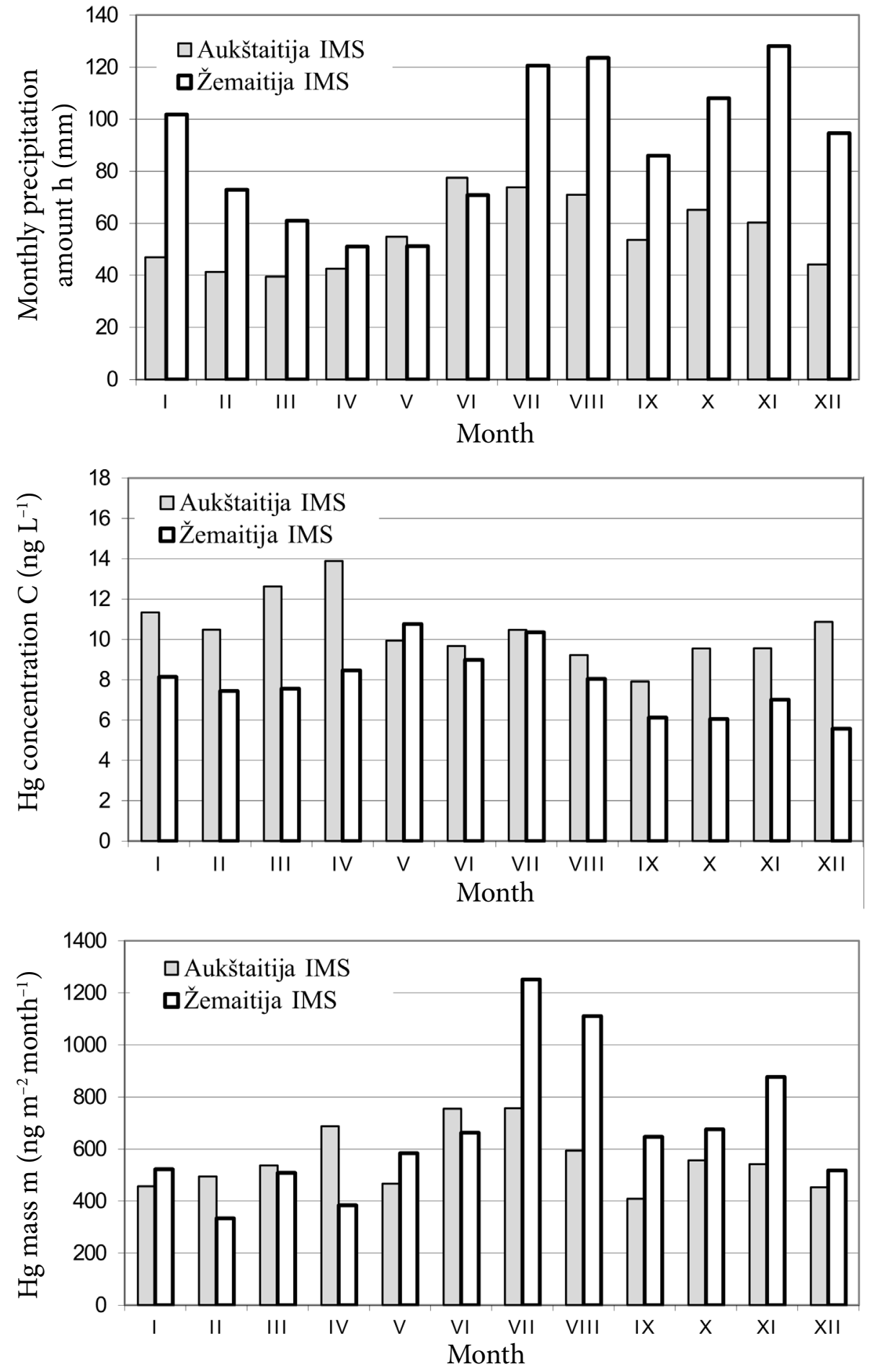

Fig. 5. The average monthly precipitation amount $(h, \mathrm{~mm})$, the average monthly concentration of mercury in precipitation $\left(C\right.$, ng $\left.\mathrm{L}^{-1}\right)$, the average mercury mass $\left(m, \mathrm{ng} \mathrm{m}^{-2}\right.$ month $^{-1}$ ) deposited at the Žemaitija and Aukštaitija integrated monitoring stations. 
surface load by mercury varied from 47.8 to $1990 \mathrm{ng} \mathrm{m}^{-2}$ month $^{-1}$ at the Aukštaitija IMS and from 24.8 to $3580 \mathrm{ng} \mathrm{m}^{-2}$ month $^{-1}$ at the Žemaitija IMS.

The tendency of average monthly mercury concentrations in the precipitation at the Žemaitija IMS was continously increasing before 2011, however, after 2012 it has a decreasing tendency which was contrary to that at the Aukštaitija IMS. At the same time, the tendencies of average monthly amounts of mercury deposited with precipitation showed decreasing amounts, especialy at the Žemaitija IMS. Explanation of the above-mentioned phenomenon is complicated and the main reason is very changeable air mass trajectories and the irregularity of precipitation.

The Earth's surface load by mercury was larger in the west of Lithuania (Žemaitija IMS) than in the east of Lithuania (Akštaitija IMS) during 20072017. A larger mercury load on the Earth's surface in the west of Lithuania was defined by a comparatively large amount of precipitation, though the average monthly mercury concentration was comparatively lower.

Precipitation irregularity, fluctuation directions of air massess and possibly changes of mercury sources did not allow us to precisely define the mercury regional trend at both mentioned stations and it seems that a much longer period of observations is needed because regional fluctations are also affected by the global climate fluctuations [34-38.

\section{Acknowledgements}

The work was supported by the Center for Physical Sciences and Technology, Lithuania, the long-term program 'Environment-friendly Power Engineering and Environment Protection Technologies' and by the Lithuanian Environmental Protection Agency under Contract No. 4F10-71.

\section{References}

[1] O. Lindquist and H. Rodhe, Atmospheric mercury - a review, Tellus 37B, 136-159 (1985), https:// doi.org/10.1111/j.1600-0889.1985.tb00062.x

[2] W. Baeyens, R. Ebinghaus, and R. Vasiliev (eds.), Global and Regional Mercury Cycles: Sources, Fluxes and Mass Balances (Kluwer Academic Publishers, Netherlands, 1996).
[3] T. Berg, O. Royset, and E. Steinnes, Trace elements in atmospheric precipitation at Norwegian background stations (1989-1990) measured by ICPMS, Atmos. Environ. 28(21), 3519-3536 (1994), https://doi.org/10.1016/1352-2310(94)90009-4

[4] Å. Iverfeldt, J. Munthe, C. Brosset, and J. Pacyna, Long-term changes in concentration and deposition of atmospheric mercury over Scandinavia, Water Air Soil Pollut. 80, 227-233 (1995), https:// doi.org/10.1007/BF01189672

[5] F. Slemr, W. Junkermann, R.W.H. Schmidt, and R. Sladkovic, Indication of change in global and regional trends of atmospheric mercury concentrations, Geophys. Res. Lett. 22, 2143-2146 (1995), https://doi.org/10.1029/95GL01790

[6] F. Slemr and H.E. Scheel, Trends in atmospheric mercury concentrations at the summit of the Wank Mountain, Southern Germany, Atmos. Environ. 32, 845-853 (1998), https://doi. org/10.1016/S1352-2310(97)00131-3

[7] W.H. Schroder and J. Munthe, Atmospheric mercury - an overview, Atmos. Environ. 32(5), 809-822 (1998), https://doi.org/10.1016/S13522310(97)00293-8

[8] C.J. Watras, K.A. Morrison, R.J.M. Hudson, T.M. Frost, and T.K. Kratz, Decreasing mercury in Northern Wisconsin: Temporal patterns in bulk precipitation and a precipitation-dominated lake, Environ. Sci. Technol. 34(19), 4051-4057 (2000), https://doi.org/10.1021/es000991g

[9] A. Urba, K. Kvietkus, and R. Marks, Gas-phase mercury in the atmosphere over the southern Baltic Sea coast, Sci. Total Environ. 259(1-3), 203-210 (2000), https://doi.org/10.1016/S00489697(00)00583-0

[10]L.D. Hylander, Global mercury pollution and its expected decrease after a mercury trade ban, Water Air Soil Pollut. 125, 331-344 (2001), https://doi.org/10.1023/A:1005231017807

[11]E. Pacyna, J. Pacyna, and N. Pirone, European emissions of atmospheric mercury from anthropogenic sources in 1995, Atmos. Environ. 35, 2987-2996 (2001), https://doi.org/10.1016 S1352-2310(01)00102-9

[12]T. Stephens, Mercury in California rainwater traced to industrial emissions in Asia, UC Santa 
Cruz Currents 6, 1-2 (2003), https://www1.ucsc. edu/currents/02-03/01-06/mercury.html

[13]X. Feng, S. Tang, L. Shang, H. Yan, J. Sommar, and $\mathrm{O}$. Lindqvist, Total gaseous mercury in the atmosphere of Guiyang, PR China, Sci. Total Environ. 304, 61-72 (2003), https://doi. org/10.1016/S0048-9697(02)00557-0

[14]I. Wängberg, J. Munthe, N. Pirrone, Å. Iverfeldt, E. Bahlman, P. Costa, R. Ebinghaus, X. Feng, R. Ferrara, K. Gårdfeldt, et al., Atmospheric mercury distribution in Northern Europe and in the Mediterranean region, Atmos. Environ. 35, 2019-2025 (2001), https://doi.org/10.1016/ S1352-2310(01)00105-4

[15]R. Ebinghaus, H. Kock, A. Coggins, T. Spain, S. Jennings, and Ch. Temme, Long-term measurements of atmospheric mercury at Mace Head, Irish west coast, between 1995 and 2001, Atmos. Environ. 36(34), 5267-5276 (2002), https://doi. org/10.1016/S1352-2310(02)00691-X

[16]C. Temme, F. Slemr, R. Ebinghaus, and J.W. Einax, Distribution of mercury over Atlantic Ocean in 1996 and 1999-2001, Atmos. Environ. 37(14), 1889-1897 (2003), https://doi.org/10.1016 S1352-2310(03)00069-4

[17]E.M. Prestbo and D.A. Gay, Wet deposition of mercury in the U.S. and Canada, 1996-2005: Results and analysis of the NADP mercury deposition network (MDN), Atmos. Environ. 43, 4223-4233 (2009), https://doi.org/10.1016/j.atmosenv.2009.05.028

[18]J. Ovadnevaitè, K. Kvietkus, and A. Maršalka, 2002 summer fires in Lithuania: impact on the Vilnius city air quality and the inhabitant's health, Sci. Total Environ. 356(1-3), 11-21 (2006), https://doi.org/10.1016/j.scitotenv.2005.04.013

[19]J.M. Caffrey, W.M. Landing, S.D. Nolek, K.J. Gosnell, S.S. Bagui, and S.C. Bagui, Atmospheric deposition of mercury and major ions to the Pensacola (Florida) watershed: spatial, seasonal, and inter-annual variability, Atmos. Chem. Phys. 10, 5425-5434 (2010), https://doi. org/10.5194/acp-10-5425-2010

[20]K. Kvietkus, J. Šakalys, and D. Valiulis. Trends of atmospheric heavy metal deposition in Lithuania,
Lith. J. Phys. 51(4), 359-369 (2011), http://dx.doi. org/10.3952/lithjphys.51413

[21]J.W. O'Dell, B.B. Potter, L.B. Lobring, and T.D. Martin, Determination of Mercury in Water by Cold Vapor Atomic Absorption Spectrometry, Method 245.1, Revision 3.0 (United States Environment Protection Agency, 1994).

[22]K. Kvietkus J. Šakalys, and A. Urba, Optical Absorption Equipment for Mercury Concentration Measurement, Patent of Lithuania, No. 3138 (1993).

[23]A. Urba, K. Kvietkus, J. Šakalys, Z. Xiao, and O. Lindqvist, A new sensitive and portable mercury vapor analyzer Gardis-1A, Water Air Soil Pollut. 80, 1209-1216 (1995), https://doi. org/10.1007/BF01189794

[24]K. Kvietkus, Z. Xiao, and O. Lindqvist, Denuderbased techniques for sampling, separating and analysis of gaseous and particulate mercury in the air, Water Air Soil Pollut. 80, 1305-1309 (1995), https://doi.org/10.1007/BF01189784

[25]D. Čeburnis, J. Šakalys, K. Armolaitis, D. Valiulis, and K. Kvietkus, In-stack emissions of heavy metals estimated by moss biomonitoring method, Atmos. Environ. 36(9), 6001-6014 (2002), https://doi.org/10.1016/S1352-2310(01)00577-5

[26]J. Šakalys, K. Kvietkus, J. Sucharova, I. Suchara, and D. Valiulis, Changes in total concentrations and assessed background concentrations of heavy metals in moss in Lithuania and the Czech Republic between 1995 and 2005, Chemosphere 76(1), 91-97 (2009), https://doi.org/10.1016/j. chemosphere.2009.02.009

[27]R. Ebinghaus, S.G. Jennings, W.H. Schroeder, T. Berg, T. Donaghy, J. Guentze, C. Kenny, H.H. Kock, K. Kvietkus, W. Landing, et al., International field intercomparison measurements of atmospheric mercury species at Mace Head, Ireland, Atmos. Environ. 33(18), 30623073 (1999), https://doi.org/10.1016/S13522310(98)00119-8

[28]J. Munthe, I. Wängberg, N. Pirrone, Å. Iverfeldt, R. Ferrara, R. Ebinghaus, X. Feng, K. Gårdfeldt, G. Keeler, E. Lanzillotta, et al., Intercomparison of methods for sampling and analysis of atmospheric mercury species, Atmos. Environ. 35(17), 
3007-3017 (2001), https://doi.org/10.1016/ \$1352-2310(01)00104-2

[29]T.H. Kuo, C.F. Chang, A. Urba, and K. Kvietkus, Atmospheric gaseous mercury in Northern Taiwan, Sci. Total Environ. 368(1), 10-18 (2006), https://doi.org/10.1016/j.scitotenv.2005.10.017

[30]A. Urba, Investigations of Mercury Fluxes in the Environment, $\mathrm{PhD}$ Thesis (Institute of Physics, Vilnius, 1999).

[31]A. Urba, K. Kvietkus, J. Šakalys, J. Didžbalis, and D. Valiulis, Method and Device for Detection of Elemental Gaseous Mercury in Air or in Other Gases, European Patent, EP 3032254 B1 (2016).

[32]A. Urba, D. Valiulis, J. Šarlauskas, K. Kvietkus, J. Šakalys, and A. Sielskis, A pilot study of different materials applied for active sampling of gaseous oxidized mercury in the atmospheric air, Atmos. Pollut. Res. 8, 791-799 (2017), https://doi. org/10.1016/j.apr.2017.01.012

[33]L. Davulienè, J. Šakalys, V. Dudoitis, A. Reklaite, and V. Ulevičius, Long-term black carbon variation in the South-Eastern Baltic Region in 20082015, Atmos. Pollut. Res. 10(1), 123-133 (2018), https://doi.org/10.1016/j.apr.2018.06.013

[34]B.S. Davis and G.F. Birch, Spatial distribution of bulk atmospheric deposition of heavy metals in Metropolitan Sydney, Australia, Water
Air Soil Pollut. 214, 147-162 (2011), https://doi. org/10.1007/s11270-010-0411-3

[35]P.S. Weiss-Penzias, D.A. Gay, M.E. Brigham, M.T. Parsons, M.S. Gustin, and A. ter Schure, Trends in mercury wet deposition and mercury air concentrations across the U.S. and Canada, Sci. Total Environ. 568, 546-556 (2016), https:// doi.org/10.1016/j.scitotenv.2016.01.061

[36]E.-G. Brunke, C. Walters, T. Mkololo, L. Martin, C. Labuschagne, B. Silwana, F. Slemr, A. Weigelt, R. Ebinghaus, and V. Somerset, Mercury in the atmosphere and in rainwater at Cape Point, South Africa, Atmos. Environ. 125, 24-32 (2016), https://doi.org/10.1016/j.atmosenv.2015.10.059

[37]A. Dommergue, P. Martinerie, J. Courteaud, E. Witrant, and D.M. Etheridge, A new reconstruction of atmospheric gaseous elemental mercury trend over 60 years from Greenland firn records, Atmos. Environ. 136, 156-164 (2016), https://doi.org/10.1016/j.atmosenv.2016.04.012

[38]J.M. Pacyna, O. Travnikov, F. De Simone, I.M. Kyrre Sundseth, E.G. Pacyna, F. Steenhuisen, N. Pirrone, J. Munthe, and K. Kindbom, Current and future levels of mercury atmospheric pollution on a global scale, Atmos. Chem. Phys. 16, 12495-12511 (2016), https://doi.org/10.5194/ acp-16-12495-2016

\title{
GYVSIDABRIO NUSĖDIMO IŠ ATMOSFEROS ILGALAIKIAI TYRIMAI LIETUVOS MONITORINGO STOTYSE
}

\author{
J. Šakalys, K. Kvietkus, I. Garbarienė, A. Urba \\ Valstybinis moksliniu tyrimu institutas Fiziniu ir technologijos mokslu centras, Vilnius, Lietuva
}

\section{Santrauka}

Darbe pateikti gyvsidabrio nusèdimo iš atmosferos ilgalaikių matavimų rezultatai Aukštaitijos ir Žemaitijos integruoto monitoringo stotyse (IMS). Lietaus kritulių bandiniai buvo imami kiekvieną savaitę 2007-2017 metais. Gyvsidabrio koncentracijos buvo matuojamos mūsu institucijoje sukurtu atominiu absorbciniu gyvsidabrio analizatoriumi „Gardis“. Prietaisas išbandytas įvairiose interkalibracijose ir yra pripažintas tarptautiniu mastu. Darbe pateiktos vidutinès mènesinès ir metinès gyvsidabrio koncentracijos, jų kitimas dešimties metų laikotarpiu ir nuseddimo kiekių ì žemès paviršių analizè. Va- karinëje Lietuvos dalyje vidutinès mènesinès gyvsidabrio koncentracijos krituliuose pamažu didèjo iki $2011 \mathrm{~m}$., tačiau nuo $2012 \mathrm{~m}$. buvo pastebėta gyvsidabrio koncentracijos mažèjimo tendencija. Rytinèje Lietuvos dalyje stebima priešinga gyvsidabrio koncentracijos svyravimo krituliuose eiga (iki 2011 m. - mažejja, nuo 2012 m. - didejja). Tuo pat metu nustatyta bendra abiems stotims žemès paviršiaus apkrovos $\mathrm{Hg}$ mažejimo tendencija, ypač ryški Žemaitijos IMS. Anksčiau aprašytus reiškinius būtų galima paaiškinti didele oro masių pernašos trajektoriju kaita ir kritulių nereguliarumu abiejose tyrimų stotyse. 